\title{
Fluorine in Water and Dental Fluorosis in a Community of Queretaro State Mexico
}

\author{
Ma Lilia A. Juárez-López ${ }^{1}$, Rafael Huízar-Álvarez², Nelly Molina-Frechero ${ }^{3}$, \\ Francisco Murrieta-Pruneda ${ }^{1}$, Yazmin Cortés-Aguilera ${ }^{2}$
}

${ }^{1}$ FES Zaragoza, Universidad Nacional Autónoma de México, Mexico City, México; ${ }^{2}$ Institute of Geology, Universidad Nacional Autónoma de México, Mexico City, México; ${ }^{3}$ Universidad Autónoma Metropolitana, Mexico City, México.

Email: huizar@servidor.unam.mx

Received May 11 ${ }^{\text {th }}, 2011$; revised June $18^{\text {th }}, 2011$; accepted July $23^{\text {rd }}, 2011$.

\begin{abstract}
The community La Llave, Queretaro State, Mexico, has not been identified by the sanitary authorities as living in a hazard area related to dental fluorosis. However; a high concentration of fluoride is found in their drinking water causing them dental fluorosis. Physical-chemical analysis was carried out in the groundwater sources to determine the prevalence of dental fluorosis risk and caries accordingly to criteria of The World Health Organization, and 154 school children of ages 10 to 13 years were examined. As a result, $1.9 \mathrm{mg} / \mathrm{L}$ of fluorine concentration in drinking water was obtained; dental fluorosis presence was detected in the school children with an incidence of about $98 \%$, in $47 \%$ of cases severe fluorosis with a dental caries index of 3.06 was traced. The groundwater sources in La Llave community contains fluorine above the limits dictated by Mexican regulations, producing serious repercussions on the health of school children, with an unnaturally high incidence of dental fluorosis.
\end{abstract}

Keywords: Fluorosis, DEAN Index, Groundwater, La Llave Querétaro, Mexico

\section{Introduction}

The Community of La Llave, Queretaro State, where this work was carried out, is located at $1900 \mathrm{~m}$ above mean see level (amsl) on the southern part of the plain that extends from El Zamorano volcano, north of Queretaro City, to San Juan del Rio City, located in the central part of Mexico (Figure 1). The plain contains some volcanic reliefs hardly $100 \mathrm{~m}$ heights above the plain surface, such as Cerro La Cruz and La Carbonera, at whose base $\mathrm{La}$ Llave is located.

The geological framework of the region is constituted by rocks of chemical composition ranging from intermediate to acid, represented by interstratified ignimbrites with pumice tuffs, both expulsed through the Caldera of Amealco. These materials are covered on the plain by alluvial deposits. Alluvial deposits consist of sediments of several sizes ranging from clay and sand to rounded blocks of different composition derived from pre-existing nearby rocks. These deposits form the most surface layer of the plain and have a thickness from 5 to $30 \mathrm{~m}$.

Comisión Estatal de Agua [1] shows the existence at La Llave's zone of an aquifer formed jointly by fractured rocks and granular sediments that reaches a thickness of
$200 \mathrm{~m}$, settlements of the region obtain their water supply from this aquifer. The geological model shows the existence of volcanic bodies of Olocene Age, suggesting the presence of high temperature in the rocks beneath, this feature is consider in determining the temperature $\left(26^{\circ} \mathrm{C}\right)$ of tapped groundwater by wells.

The La Cruz, La Carbonera, and Viejo hills are constituted by ignimbrites, rhyolites, and tuffs rocks. Containing abundant fluorine where groundwater dissolves accessory minerals contained in rocks such as, mica, amphibole and apatite, the later releases fluorine to groundwater.

On the other hand, groundwater rich in $\mathrm{HCO}_{3}$, during the interaction between water and mineral (fluorite) the following reaction takes place [2]

$$
\begin{gathered}
\mathrm{CaF}_{2}+\mathrm{NaCO}_{3} \rightarrow \mathrm{CaCO}_{3}+2 \mathrm{~F}+2 \mathrm{Na} \\
\mathrm{CaF}_{2}+\mathrm{NaHCO}_{3} \rightarrow \mathrm{CaCO}_{3}+2 \mathrm{Na}+2 \mathrm{~F}+\mathrm{H}_{2} \mathrm{O}+\mathrm{CO}_{2}
\end{gathered}
$$

According to this reaction high contents of $\mathrm{NaHCO}_{3}$ in water increase the $\mathrm{CaF}_{2}$ dissolution in the rock releasing fluoride in the groundwater. The dissociation of fluorine-rich minerals, is also favored by the existence of rich mineral calcite $\left(\mathrm{CaCO}_{3}\right)$, as shown in the following reactions [3]. 


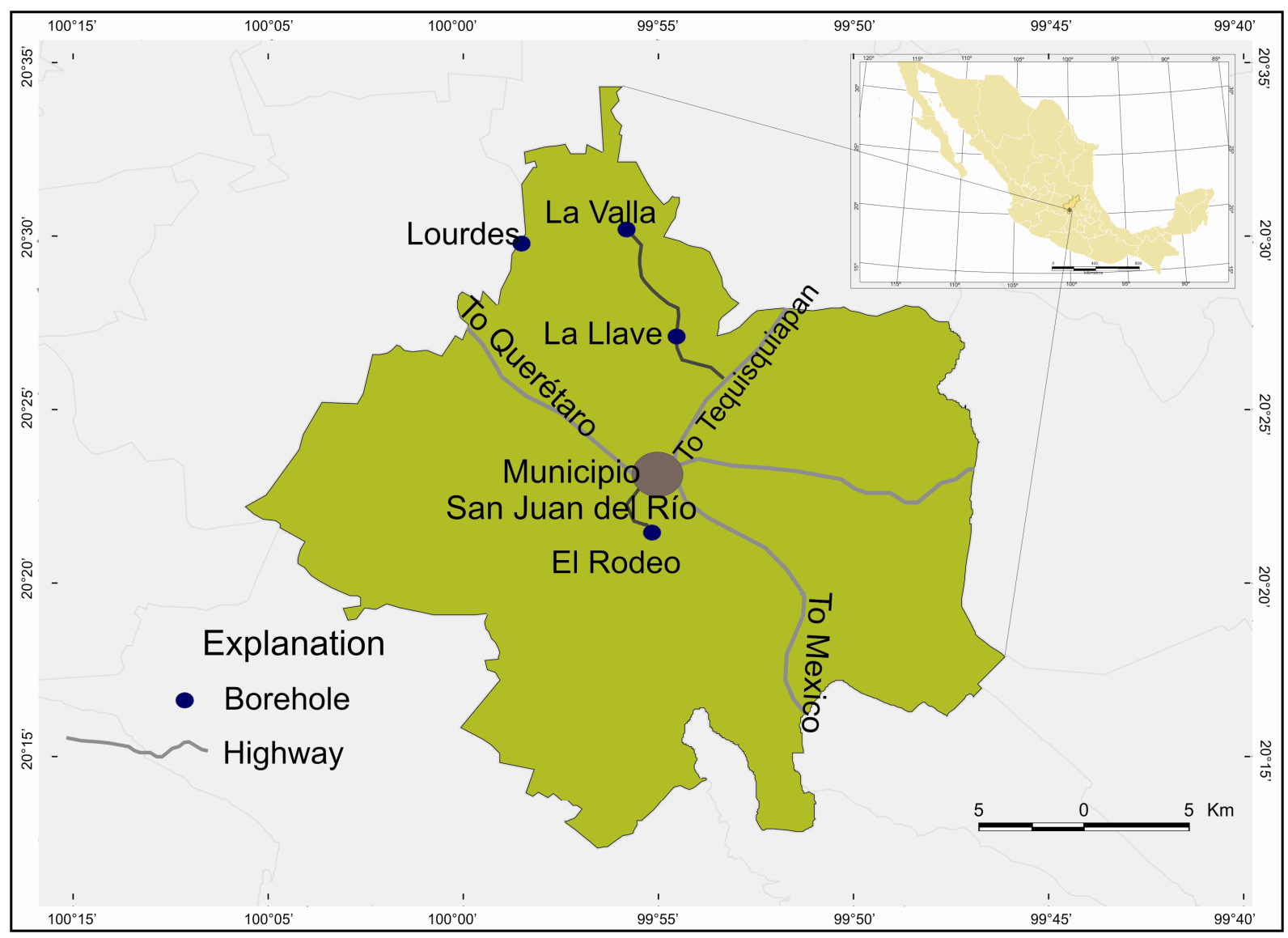

Figure 1. Location of groundwater sample borehole.

$$
\begin{gathered}
\mathrm{CaCO}_{3}+\mathrm{H}+2 \mathrm{~F} \rightarrow \mathrm{CaF}_{2}+\mathrm{HCO}_{3} \\
\mathrm{CaF}_{2} \rightarrow \mathrm{Ca} 2 \mathrm{~F} \\
\mathrm{~K}=\left\{\mathrm{a}\left(\mathrm{HCO}_{3}\right)\right\} /\{\mathrm{a}(\mathrm{H}) * \mathrm{a}(\mathrm{F})\}
\end{gathered}
$$

where $\mathrm{K}$ is the equilibrium constant, a is the activity. If $\mathrm{pH}$ is constant, the activity of fluorine is directly proportional to $\mathrm{HCO}_{3}$. This relationship is independent of $\mathrm{Ca}^{2+}$ produced by the low solubility of $\mathrm{CaF}_{2}$.

Fluorine content in groundwater is positively correlated with $\mathrm{Na}^{+}$and $\mathrm{pH}$, the presence of $\mathrm{F}^{-}$; is associated with sodium bicarbonate type water with a high $\mathrm{pH}$. However, it has a negative correlation with $\mathrm{Ca}^{2+}$, this indicates that the fluorine concentration is associated with reactions where $\mathrm{Na}^{+}$and $\mathrm{pH}$ increase, and $\mathrm{Ca}^{2+}$ decreases as a result of cation exchange, or precipitation of calcite. This suggests that $\mathrm{F}^{-}$concentration is controlled by the Fluorite $\left(\mathrm{CaF}_{2}\right)$ equilibrium, i.e., the limits of fluorine are determined by the calcium ion [4-8].

According to Edmunds [9], the upper limit on fluoride activity in aqueous solutions is controlled by the solution of the products, $\mathrm{K}_{\text {fluorite }}$

$$
\begin{gathered}
\mathrm{CaF}_{2}=\mathrm{Ca}^{2+}+2 \mathrm{~F}^{-} \\
\mathrm{K}_{\text {fluorita }}=\left(\mathrm{Ca}^{2+}\right)\left(\mathrm{F}^{-}\right)^{2}=10^{-10.57} \text { at } 25^{\circ} \mathrm{C} \\
\text { or, } \log \mathrm{K}_{\text {fluorita }}=\left(\mathrm{Ca}^{2+}\right)+2 \log \left(\mathrm{F}^{-}\right)=-10.57
\end{gathered}
$$

Those equations show that in the presence of fluoride, the fluorine contents are inversely proportional to $\mathrm{Ca}^{2+}$. The silicates dissolution in alkaline rocks, where oligoclase is plagioclase dominant, rich in sodium and calcium deficient, provides sodium and fluorine enrichment in groundwater $[6,10,11]$. Based on the foregoing, $\mathrm{F}^{-}$can be removed by precipitation when there is a high concentration of $\mathrm{Ca}^{2+}[7]$.

Fluorosis is a disturbance caused by excessive ingestion of fluorine during the odontogenic stage [12]. In Mexico, the prevalence and incidence of fluorosis have increased during the past years, as a result of ingestion of fluorine during dental formation by means of water, food prepared with fluorated salt, and inadvertent ingestion of this element during dental brushing with fluorated toothpaste, as well as hidden fluorine in beverages [13,14].

In light of dental spots observed to children of this 
community and the lack of reports related to the fluorine concentration in water in this area, it was considered to be important to carry out the present study. The goal of this study is to determine the fluorine concentration in drinkable water, as well as to analyze the effects of fluorosis and dental caries in school children residents in La Llave town.

\section{Methodology}

\subsection{Water Sample}

Samples of water were taken for physical chemical analysis in polyethylene bottles prewashing in lab with hydrochloric acid (5\%) and distilled water solution. Air bubbles were avoided to limit any potential change in the original chemical water composition. A $100 \mathrm{ml}$ bottle was taken without adding any preservation agent or filtered, this sample was used in anions determination. The sample for cations and trace elements was taken in a bottle of $125 \mathrm{ml}$; it was filtered using a cellulose acetate membrane of $0.45 \mu \mathrm{m}$ and was then acidified (to a $\mathrm{pH} \approx 2$ ) by means of nitric acid of high purity (in order to avoid precipitation and absorption of elements on the walls of the bottle). Analyses were carried out by a mass spectrometer with inductive plasma coupling (ICP-MS). The detection limits obtained with this equipment is very low (less than $0.001 \mathrm{mg} / \mathrm{l}$ ). The analyses were performed by Actlabs of Canada.

\subsection{Clinical Examination}

For convenience, the 154 subjects, between 10 to 13 years old, were checked; all of them are residents of the community La Llave, Municipality of San Juan del Rio, Queretaro. Only children with explicit permission from their parents participated in this study, their residence greater than 10 years in the zone was also demonstrated. Children with background of metabolic disease or those under orthodontic treatment were excluded from the study.

The clinical examinaton was carried out with natural light without desiccation, using dental plain mirrors, \#5, without amplification. Results were recorded in individual files. The exam was performed by two qualified and standardized observers accordingly to the WHO criteria [15]. Among the Dean Fluorosis Index (ID) and dental caries index (DMF-T and DMF-S), when the Kappa test was applied, congruence was observed in the diagnosis criteria of $87 \%$ and $95 \%$ for fluorosis caries index respectively.

\section{Results and Discussion}

\subsection{Water Quality}

According with the prevailing geological framework, the chemical quality of the water that the population drinks depends of the type of rock material it circulates through. Consequently, fluorine concentration in the aquifer is associated to rock-water interaction and is determined on the one hand by the abundance in the minerals forming the rocks $[16,17]$, as well as by the solubility of the minerals, and the water subsaturation as related to calcite. In as much as the calcium limits the solute or dissolved fluorine concentration[18], Table 1 contains the chemical analytical results for this paper, where it can observed that the greater calcium content the lower content of fluorine, and vice-versa. Based on the solubility control of fluoride it may be removed by precipitating it by maintaining a high concentration of $\mathrm{Ca}^{2+}$ [7], these researchers propose that fluorine dispersion and transport are determined by $\mathrm{pH}$ and water temperature.

In a laboratory experiment, the quantity of solute or dissolved fluorine in acidic rocks was found to be almost double the quantity to that in basic rocks; this also showed the close relationship between fluorine content in groundwater and the nature of strata it flows through [19].

In most of the towns of Mexico, the water supply is derived from groundwater sources, whose natural mineralization has increased in some elements such as fluorine [20], In many cases, the result depended on the way the water is extracted. i.e., an intense extraction of ground

Table 1. Groundwater chemical composition of the wells analyzed in this study (Lourdes, La Valla, and La Llave), values in $\mathrm{mg} / \mathrm{L}$.

\begin{tabular}{ccccc}
\hline Parameter & Lourdes & Llave & Valla & WHO $(\mathrm{g} / \mathrm{v})$ \\
\hline $\mathrm{pH}$ & 8.05 & 8.10 & 8.07 & $\mathrm{n}-\mathrm{h}$ \\
Water temp & $31.0^{\circ} \mathrm{C}$ & $30.0^{\circ} \mathrm{C}$ & $25.9^{\circ} \mathrm{C}$ & $\mathrm{n}-\mathrm{h}$ \\
Alcalinity & 140.00 & 107.00 & 150.00 & $\mathrm{n}-\mathrm{h}$ \\
$\mathrm{Ca}^{2+}$ & 22.00 & 12.10 & 21.00 & $\mathrm{n}-\mathrm{h}$ \\
$\mathrm{Mg}^{2+}$ & 5.61 & 3.16 & 7.92 & $\mathrm{n}-\mathrm{h}$ \\
$\mathrm{K}^{+}$ & 10.50 & 10.10 & 13.70 & $\mathrm{n}-\mathrm{h}$ \\
$\mathrm{Na}^{+}$ & 40.00 & 45.00 & 42.00 & $\mathrm{n}-\mathrm{h}$ \\
$\mathrm{Cl}^{-}$ & 3.79 & 4.84 & 3.95 & $\mathrm{n}-\mathrm{h}$ \\
$\mathrm{SO}_{4}^{2-}$ & 6.91 & 7.35 & 10.40 & $\mathrm{n}-\mathrm{h}$ \\
$\mathrm{Si}$ & 37.00 & 43.50 & 39.20 & $\mathrm{n}-\mathrm{h}$ \\
$\mathrm{Mn}$ & 0.05 & 0.01 & 0.01 & 0.4 \\
$\mathrm{Fe}$ & 0.10 & 0.10 & 0.10 & $\mathrm{~N}-\mathrm{H}$ \\
$\mathrm{F}^{-}$ & $\mathbf{0 . 5 2}$ & $\mathbf{1 . 9 4}$ & $\mathbf{0 . 5 1}$ & $\mathbf{1 . 5}$ \\
\hline
\end{tabular}

WHO (g/v), Guideline value; $\mathrm{n}-\mathrm{h}=$ Not of health concern at levels found; in drinking-water. 
water causes the drawdown of the water-table in wells and induces water flow from the deeper levels [21], where their mineral content might contribute with fluorine in higher concentration than those considered, as optimal for fluorosis prevention. However, in wells, where water is extracted from low depth obtaining local or intermediate flows with traces of fluoride can reduce significantly the levels of fluoride in the obtained water.

The water extracted from the well in La Llave contained more fluorine than those in neighboring towns as Lourdes and La Valla (Table 1). However, that content is low related to those reported in other regions in the country also of volcanic origin, such as San Luis Potosí (4 - 7 mg/L), [22], Tesistan Jal. (4.7 mg/L), [23], and Durango $(5.7 \mathrm{mg} / \mathrm{L})$ [24]. In agree to groundwater flow systems model [25], the records of fluorine content and temperature in the first three wells, led to assumption that the obtained water is related to a groundwater flow system of local type; whereas, for the other regions, it is more related to an intermediate flow.

\subsection{Dental Fluorosis}

The prevalence of students affected by dental fluorosis was $98 \%$, this dental defect is regarded as a biomarker of chronic toxicity caused by continuous exposure to fluorine. The Community Dean Index (CDI) was $3.06 \pm 1$. Moreover, approximately $48 \%$ of those children showed severe fluorosis (Table 2) with loss of dental enamel structure requiring prosthetic and anti-aesthetic actions.

The Table 3 shows the mean of the different index by gender, and the percentage of children with dental caries was $70 \%$ with a DMFT of $2.7 \pm 2.7$ and a DMFS of $3.6 \pm$ 3.7.

The prevalence of caries was greater in those children with high severe fluorosis (Figure 1). There is information about low levels of fluorosis preventing caries, but severe levels constitute a risk factor for diseases since the structural defects due to fluorosis alterations cause spots where the bacterial plaque can remain [26].

Present study coincides in the general objective regarding the communities of La Fuente, Santillan, and San José, all located close to San Juan del Rio Queretaro, where a prevalence of $87 \%$ of fluorosis in children from 11 to 13 years of age, has been reported [27].

In the village of La Llave, the dental fluorosis could be related not only with the fluoridated drinking water above optimal limit level, but also by preparing meals and milk formula, in addition fluoride is also ingested through foods prepared with fluoridated salt.

Some authors report that the more fluorosis affected populations are those located at high altitude [28]. At $1500 \mathrm{~m}$ high amsl renal filtration and filtration of some substances are modified to favor an increase of fluorine
Table 2. Severity of fluorosis according to the DEAN index affecting scholars of 10 - 13 years old at the Community La Llave.

\begin{tabular}{ccc}
\hline Severity of Fluorosis $^{*}$ & F & $\%$ \\
\hline None Fluorosis & 3 & 2.0 \\
Very slight & 13 & 8.0 \\
Slight & 29 & 19.0 \\
Moderate & 36 & 23.5 \\
Severe & 73 & 47.5 \\
Total & 154 & 100.0 \\
\hline
\end{tabular}

${ }^{*}$ Criteria of Dean.

Table 3. Dental fluorosis and caries index by gender in scholars of 10 to 13 years old at the Community La Llave.

\begin{tabular}{cccccccc}
\hline & \multicolumn{2}{c}{ IDC } & \multicolumn{2}{c}{ DFMT } & \multicolumn{2}{c}{ DMFS } \\
\hline & $\mathrm{X}$ & $\mathrm{DE}$ & $\mathrm{X}$ & $\mathrm{DE}$ & $\mathrm{X}$ & $\mathrm{DE}$ \\
Men & $3.05-3.04$ & 1.02 & 2.75 & 2.8 & 3.7 & 3.8 \\
Women & $3.11-3.08$ & 1.06 & 2.82 & 2.6 & 3.55 & 3.5 \\
\hline
\end{tabular}

$\mathrm{X}=$ Mean. $\mathrm{DE}=$ Standard deviation. $\mathrm{IDC}=$ Community Dean Index. DFM-T $=$ Decayed Filled Missed Teeth. DMFS = Decayed Filled Missed Teeth by Surface

in the blood, which eventually will be concentrated in teeth and bones [29]

\section{Conclusions}

Fluorine concentration in water supplied to La Llave village had a $1.9 \mathrm{mg} / \mathrm{L}$ concentration. Continuous chemical monitoring of water quality is considered relevant; it has to be performed in the wells and water supply plants of nearby zones to geographically determine an acceptable and required fluorine characterization.

The results obtained in this paper highlights differences of dental fluorosis showing that the maternal and offspring population are exposed to various sources of fluoride that cause floruosis; these sources are:

- Boil drinking water

- Food prepared with water having high fluoride content

- Cooking with fluoridated salt

Boiling water consumption rises from $60 \%$ to $70 \%$ the original concentration of fluoride, which puts at risk for developing fluorosis in permanent teeth [14,30,31].

A high fluorosis prevalence was observed, the IDC points a severe public health problem, so it is important to consider that well-water purification systems will be installed in La Llave village or that other sources for supplying potable water will be needed. It appears a valid 
proposal that the inhabitants receive information related to the fluoride sources related to dental fluorosis risks.

\section{REFERENCES}

[1] Comisión Estatal de Agua, "Estudio Integral del Recurso Agua en los Acuíferos del Estado de Querétaro," 2000.

[2] A. H. Brownslow, "Geochemistry," Prentice Hall, Upper Saddle River, 1996.

[3] V. K. Saxena and S. Ahmed, "Dissolution of Fluoride in Groundwater: A Water-Rock Interaction Study," Environmental Geology, Vol. 40, No. 99, 2001, 1084-1087.

[4] J. U. Lee, H. T. Chon and Y. W. John, "Geochemical Characteristics of Deep Granitic Groundwater in Korea." Journal of the Korean Society of Groundwater Environment, Vol. 4, 1997, pp. 199-211.

[5] K. Kim and S. T. Yun, "Buffering of Sodium Concentration by Cation Exchange in the Groundwater System of a Sandy Aquifer," Geochemical Journal, Vol. 39, No. 3, 2005, pp. 273-284. doi:10.2343/geochemj.39.273

[6] G. T. Chae, S. T. Yun, M. J. Kwon, Y. S Kim and B. Mayer, "Batch Dissolution of Granite and Biotite in Water: Implication for Fluorine Geochemistry in Groundwater," Geochemical Journal, Vol. 40, No. 1, 2006, pp. 95-102. doi: $10.2343 /$ geochemj.40.95

[7] G. T. Chae, S. T. Yun, B. Mayer, K. H. Kim, S.Y. Kim, J. S. Kwon, K. Kim and Y. K. Kohn, "Fluorine Geochemistry in Bedrock Groundwater of South Korea," Science of the Total Environment, Vol. 385, No. 1-3, 2007, pp. 272283. doi:10.1016/j.scitotenv.2007.06.038

[8] T. S. Rafique, T. H. Naseem, E. Usmani, F. Bashir, A. Khan and M. I. Bhanger, "Geochemical Factors Controlling the Occurrence of High Fluoride Groundwater in the Nagar Parkar Area, Sindh, Pakistan," Journal of Hazardous Materials, Vol. 171, No. 1-3, 2009, pp. 424-430. doi:10.1016/j.jhazmat.2009.06.018

[9] W. M. Edmunds and P. L. Smedley, "Fluoride in Natural Waters," In: O. Selinus, Ed., Essential of Medical Geology, Impacts of the Natural Environment on Public Healt, Elsevier Academic Press, Amsterdam, 2005, pp. 301-329.

[10] D. W. Hyndman, "Petrology of Igneous Rocks," 2nd Edition, McGraw-Hill, Inc., New York, 1985.

[11] L. A. Raymond, "Petrology, the Study of Igneous Sedimentary \& Metamorphic Rocks," 2nd Edition, Mc Graw Hill, New York, 2002.

[12] C. Robinson, S. Connell, J. Kirkham, S. J. Brookes, R. C. Shore and A. M. Smith, "The Effect of Fluoride on the Developing Tooth," Caries Research, Vol. 38, No. 3, 2004, pp. 268-76. doi:10.1159/000077766

[13] M. Grimaldo. M, Borja-Aburto, V. H, Ramírez, A. L. Ponce and F. Díaz-Barriga, "Endemic Fluorosis in San LuÍS PotosÍ. MÉXico; Identification of Risk Factors Associated with Human Exposure to Fluoride," Environmental Research, Vol. 68, No. 1, 1995, pp. 25-30. doi:10.1006/enrs.1995.1004

[14] J. P. Loyola-Rodríguez, A. Pozos-Guillén, A. Rueda-
González, S. Vázquez-Moctezuma and G. De la PazDomínguez, "Factores de Riesgo a Fluorosis Dental en San Luis Potosí, México," Asociación Dental Mexicana, Vol. 6, 1996, pp. 295-300.

[15] World Health Organization, "Oral Health Survey-Basic Methods," 3rd Edition, WHO, Geneva, 1997.

[16] B. Gizaw, "The Origin of High Bicarbonate and Fluoride Concentration in Waters of the Main Ethiopian Rift Valley, East African Rift System," Journal of African Earth Sciences, Vol. 22, No. 4, 1996, pp. 391-402. doi:10.1016/0899-5362(96)00029-2

[17] J. Dowgiallo, "Thermal Water Prospecting Results at Jelenia GÓRa-Cieplice (Sudetes, Poland) versus Geothermometric Forecasts," Environmental Geology, Vol. 39, No. 5, 2000, pp. 433-6.

[18] A. Cardona and J. J. Carrillo-Rivera, "Control EquilibrioSolubilidad en la Concentración de Fluoruro en el Agua Subterránea del Centro de México," Actas INAGEQ, Vol. 1, 1995, pp. 51-56.

[19] L. F. S. Díaz, "Hidrogeología del Sistema TesistanToluquilla, Jalisco," Ph.D. Dissertation, Ciencias de la Tierra, Universidad Nacional Autónoma de México, 2007.

[20] Secretaría de Salud: Norma Oficial Mexicana NOM-127SSA1-1994, "Salud Ambiental, Agua Para Uso y Consumo Humano. Límites Permisibles de Calidad y Tratamientos a que Debe Someterse el Agua Para su Potabilización México," Diario Oficial/18-Enero-1996, 1996.

[21] J. J. Carrillo-Rivera and B. A. Cardona, "Groundwater Flow System Response in Thick Aquifer Units: Theory and Practice in Mexico," 53-IAH International Congress, Zacatecas, AIH, Editorial Balkema, Taylor \& Francis Group, Leiden, Vol. 12, 2008, pp. 25-46.

[22] P. Medellin, T. Alfaro, S. A. De Lira, A. B. Nieto and M. I. Sarabia, "Fluoride in Drinking Water, Its Correlation with Parameters of the Aquifer and Effect on Dental Health in the City of San Luis Potosi Mexico," Proceedings Water Quality Technology Conference, American Water Works Association, Vol. 2, 1993, pp. 1011-1024.

[23] H. L. González, L. F. Sánchez and A. I. Mata, "Estudio Hidro-Geoquímico e Isotópico de la Zona de ToluquillaTesistan, Jal. Mexico," CNA-IMTA, 1994.

[24] V. R. Trejo, H. M. T. Alarcón, L. Y. Martínez, N. P. Romero and M. J. Salvador, "Niveles de Fluoruros en el Agua de los Pozos de la Ciudad de Durango," Ingenieria Hidraulica en Mexico, Vol. 12, No. 3, 1997, pp. 51-57.

[25] J. Töth, "Groundwater as a Geologic Agent," Journal of Hydrology, Vol. 7, No. 1, 1999, pp. 1-14

[26] J. Lalumandier and R. G. Rozier, "Parent's Satisfaction with Children's Tooth Color Fluorosis as a Contributing Factor," Journal of the American Dental Association, Vol. 129, No. 7, 1998, pp.1000-1006.

[27] S. Sánchez-García, A. Pontigo-Loyola, E. Heredia-Ponce and J. Ugalde-Arellano, "Fluorosi Dental en Adolescentes de Tres Comunidades del Estado de Querétaro," Revista Mexicana de Pediatría, Vol. 72, No. 1, 2004, pp.5-9. 
[28] L. Mabelya, K. G. Koning and Van P. W. H. Helderman, "Dental Fluorosis, Altitude, and Associated Dietary Factors," Caries Research, Vol. 26, No. 1, 1992, pp. 65-67. doi: $10.1159 / 000261430$

[29] M. R. Kramer, C. Springer, N. Berkman and M. Glazer, "Rehabilitation of Hypoxemic Patients with Coped at Low Altitude at the Dead Sea, the Lowest Place on Earth,” Chest, Vol. 99, No. 113, 1998, pp. 571-575. doi:10.1378/chest.113.3.571
[30] J. P. Loyola Loyola-Rodríguez, A. J. Pozos-Guillen and J. C. Hernández-Guerrero, "Bebidas Embotelladas Como Fuentes Adicionales de Exposición a Flúor," Salud Pública Méx, Vol. 40, No. 5, 1998, pp. 438-41.

[31] F. Díaz-Barriga, R. Leyva, J. Quistian, J. P. LoyolaRodríguez, A. Pozos and M. A. Grimaldo, "Endemic fluorosis in San Luis Potosi, Mexico IV. Sources of fluoride exposure," Fluoride, Vol. 30, 1997, pp. 219-222. 